\title{
State Civil Apparatus in Indonesia in the Conception of Welfare State: A Study of Legal Material Law Number 5 Year 2014 on State Civil Apparatus
}

\author{
Mukmin Muhammad $^{1} \&$ La Ode Husen ${ }^{1}$ \\ ${ }^{1}$ Department of Administrative Law, Universitas Muslim Indonesia, STIA Al Gazali Barru, Indonesia \\ Correspondence: Mukmin Muhammad. E-mail: mukmintomy48048@gmail.com
}

Received: February 4, 2019

Accepted: February 20, 2019

Online Published: February 28, 2019

doi:10.5539/ass.v15n3p64

URL: https://doi.org/10.5539/ass.v15n3p64

\begin{abstract}
In essence every form of government interference must be based on legislation that applies as a principle of legality, which is the main joint law of the State. However, because there are limitations to this principle or because of weaknesses and shortcomings in the laws and regulations, the government is given freedom. Freies Ermessen, namely the freedom of the government to be able to act on its own initiative in solving social problems. Freies Ermessen raises opportunities for conflicts of interest, in order to avoid or minimize violations of citizens' rights, hence increasing legal protection for deviant state administration (Verhoogde Rechtsbescherming) in the form of "Algemene Beginselen Van Behoorlijk Bestuur" or general principles of good governance. The task of government is carried out in the framework of the implementation of the general functions of government which includes institutional, personnel and management utilization. Whereas in the implementation of certain development tasks carried out in the context of implementing certain development tasks carried out through nation-building (cultural and political development) as well as through economic and social development (economic and social development) which is directed at increasing the welfare and prosperity of the entire community, Law Number 5 Year 2014 on state civil apparatus as the basis for regulating the state civil apparatus in each of its implementation policies prioritizes the foundation of legislation, propriety and justice. The method of research is normative legal research methods, namely the study of legal principles legal rules which are standards for behaving or behaving. This research can be carried out (especially) on primary and secondary legal materials, as long as the materials contain legal rules, because not every article in a law, for example, contains legal rules; there are articles which are only limits as commonly found in the general provisions of the legislation. Research on legal principles is a philosophical study because the legal principle is an ideal element of law. Goals: The purpose of this research is to make the state civil apparatus understand the concept of the welfare state, the use of discretionary power (Freies ermessen), understand the principles that limit the actions of state civil apparatus to avoid corruption and collusion and nepotism in realizing people's welfare in Indonesia. Novelty/Improvement: This article discusses the study of law regarding the position of Civil Servants in Indonesia based on Law Number 5 Year 2014 on State Civil Apparatus. Concerning state civil apparatus which is associated with principles general good governance, this research article is also expected to be able to provide information for readers to be able to realize the state civil apparatus free from the practice of collusion, corruption and nepotism in realizing good governance in Indonesia in the conception of welfare state.
\end{abstract}

Keywords: state, civil, government, ermessen, apparatus, welfare

\section{Introduction}

The aim of the Indonesian people as confirmed in the preamble of the 1945 Constitution of the Republic of Indonesia was to establish an Indonesian state government that protected all Indonesian people and all of Indonesia's bloodshed, to promote public welfare, educate the nation's life, and participate in lasting peace and social justice.

Protecting all the Indonesian people and the whole bloodshed of Indonesia means guaranteeing every Indonesian nation to obtain their respective rights and obligations. advancing general welfare is the duty of the unitary State of the Republic of Indonesia to advance the standard of living, from the community to achieve prosperity for the people as a whole. Educating the life of the nation is done so that the younger generation can replace leaders in 
the present. Participating in maintaining world order based on independence, eternal peace and social justice is the ideal of world peace by involving all elements of the state in the world to achieve order and peace.

To achieve these objectives based on Pancasila and the 1945 Constitution of the Republic of Indonesia, national development was carried out in Indonesia. In order for the planning stage to carry out the tasks of national development and the task of government to be able to run, as expected, good governance is needed. In the smooth running of government / state administration, it depends mainly on the perfection of its personnel apparatus. State Civil Service Administration is regulated in Law Number 5 Year 2014 on State Civil Apparatus (State Civil Apparatus) and other laws and regulations.

The duties and responsibilities of the bureaucracy as public servants are very complex, namely being responsible for the ideology and foundation of the state, government, political parties, law, rules, official, professional ethics and society. Kumorotomo (Note 1) stated that the form of government bureaucratic organization that has responsiveness to the interests of the community has basic characteristics:

\section{Oriented to the needs of service users.}

2. Be creative and innovative.

3. Assume human resources as long-term fixed capital.

4. Leadership that has the ability to unite various interests in the organization, so as to foster synergism.

Therefore, the government apparatus must be more sensitive to the needs of the community and not discriminate between services between citizens and other citizens. Community service is becoming increasingly important because it always relates to the public or people. Thoha (Note 2) explained that community service in order to achieve certain goals, to provide assistance to the public in order to achieve certain goals, and government bureaucracy is the foremost instruction relating to the provision of public services.

To form the State Civil Service (state civil apparatus) that is able to provide public services and carry out its role as an adhesive to the unity and unity of the Republic of Indonesia, it is necessary to replace Law Number 8 Year 1974 concerning the principles of staffing as amended by the Law. Law Number 43 Year 1999 concerning changes to Law Number 8 of 1974 concerning the main points of employment. As a substitute, namely Law Number 5 Year 2014 on State Civil Apparatus.

\section{Literature Study}

Discussing the context of public law, employees of the state civil apparatus are tasked with assisting the president as head of government in administering the government, namely by implementing legislation, in the sense that the word is obliged to ensure that every law is adhered to by the community.

In implementing legislation in general, employees of the state civil apparatus are given official duties to be carried out as well as possible. As a servant of the state, an employee of the state civil apparatus must also be loyal and obedient to Pancasila as a philosophy and ideology of the state, to the 1945 Constitution of the Republic of Indonesia, to the state, and to the government. Employees of the state civil apparatus as elements of the state apparatus, state servants and public servants are required to be able to carry out their national civil administration properly, therefore they must have loyalty, full obedience to Pancasila, 1945 Constitution of the Republic of Indonesia, state and government so that they can focus all attention and thought and directing all efforts and energy to carry out the tasks of government and development in an efficient and effective manner. The position of the state civil apparatus under Law Number Year 2014 is regulated in article 8 where the state civil apparatus is located as an element of the state apparatus.

Based on Law No. 5 Year 2014, Functions, Tasks, and Roles of the state civil apparatus are regulated in CHAPTER IV article 10, article 11, and article 12. That is as follows:

a. Based on article 10, employees of the state civil apparatus have the function of implementing public policies, public servants, and adhesives and unifying the nation.

b. Based on Article 11, civil apparatus of the state have the duty to implement public policies made by staff development officer in accordance with the provisions of legislation, provide professional and quality public services, and strengthen the unity of the Unitary State of the Republic of Indonesia.

c. Based on Article 12 the role of employees of the state civil apparatus is as a planner, executor, and supervisor of the implementation of general tasks of government and national development through the implementation of professional policies and public services, free from political intervention, and clean from Nepotism Corruption Collusion practices. 
Government in running the government consists of political government and administrative government, the implementation of non-political techniques (state administration). Carrying out government (in the limited and political sense) means (Note 3):

1. Make and establish regulations that have the strength or nature of the Act. The Law is any general, abstract, impersonal and imperative regulation or provision which means it is compelling and cannot be resisted by anyone.

2. To provide guidance to the people of the country (to control, summon, education, counseling, etc.) without regard to individuals.

3. Running the police (acting directly against any violator of the Law indiscriminately).

4. Conducting a court (completing a legal dispute and forming a court body for it).

Political functions are related to policy making or the formulation of statements of the state's wishes, while administrative functions are concerned with implementing these policies (to do with the execution of these policies).

Political functions are related to policy making or formulation of statements of state wishes while administrative functions are concerned with implementing the policy.

In carrying out this government the government takes various kinds of decisions that are political in nature (relying on state power) in various forms, each other depending on the material and the purpose consisting of rules, strategies, policies, plans, budgets, instructions, orders, and so on. These government decisions are of a general nature and mean that they are not intended to or against a person or entity or a particular case, but are rules or general principles or general provisions, because they aim to solve problems or deal with matters of public interest, either state interests or public interest. Decisions (wills) of government are run by the State Administration

In order to realize national goals, civil servants of the state are required to be assigned the task of carrying out public service tasks, government duties and certain development tasks. The task of public services is carried out by providing services for goods, services, and / or administrative services provided by state civil apparatus employees.

The task of the government is carried out in the framework of the implementation of the general functions of the government which includes the utilization of institutions, staffing and management. Whereas in the implementation of certain development tasks carried out in the context of implementing certain development tasks carried out through national development (cultural and political development) as well as through economic and social development which is directed at increasing the welfare and prosperity of the entire community,

Law Number 5 Year 2014 on state civil Apparatus as the basis for regulating the state civil Apparatus in the same period of policy as prioritizing the foundation of legislation, decency and justice.

The Indonesian state is a welfare state which is an evolution from an ancient country that was only a night watchman. The consequence of the welfare state is that the state intervenes in all forms of community activities to ensure the implementation of public welfare. In this case the role of the government is very broad in interfering in community activities (Note 4). The shift in the concept of Patronage State (nachwachtersstaat) to the conception of the welfare state, brought a shift to the role and activities of the government, in the conception of welfare state, the government was given the obligation to realize general welfare (bestuurszorg).

Basically, any form of government intervention must be based on legislation that applies as the principle of legality, which is the main joint law of the State. However, because there are limitations to this principle or because of weaknesses and shortcomings in the laws and regulations, the government is given freedom/ discretion (Freies Ermessen) (Note 5), that is the freedom of the government to be able to act on its own initiative in solving social problems (Note 6). Freis Ermessen increased the chances of conflicts of interest between the government and the people in the form of onrechmatig overheidsdaad, detournement de pouvoir which is a form of government arbitrariness that causes violations of citizens' human rights.

In order to avoid or minimize the occurrence of violations of human rights of citizens, legal protection is increased for the people from the actions of the state administration deviant (Verhoogde Rechtsbescherming) in the form of "Algemene Beginselen Van Behoorlijk Bestuur" or general principles of good governance.

\section{Research Method}

The research method is a normative legal research method, which is a study of legal principles carried out 
against legal principles which are standards of behavior. Such research can be carried out (especially) on primary and secondary legal materials, insofar as the material contains legal rules, because not every article in the law, for example, contains legal rules; there are articles which are only limitations as commonly found in the general provisions of the law. Research on legal principles is a philosophical study because legal principles are ideal legal elements. These legal principles, both constitutive and regulative, can be discussed, analyzed according to the legal field, for example State Administrative Law and civil law.

HJ. Van Eikema Hommes (Note 7) stated that in the Law of State Administration known as the principles; the responsibility of the state for the attitude of state officials, the principle that agreements between administrative institutions and other parties must not impede the enforcement of general rules, appropriate principles of governance (regulative legal principles) in particular are "Salus Publica Suprema Lex Esto".

Flow Chart: To research the role of state civil apparatus in the concept of welfare state as a study of the legal material of law number 5 Year 2014 on state civil apparatus, Research is designed to follow a conceptual diagram as shown below:

- General principles of good governance
- law number 5 Year 2014 on state civil apparatus
- The realization of the State Civil Apparatus that is able to provide public services and as an
adhesive for the nation's unity and integrity in the concept of a welfare state

Figure 1. Conceptual research framework

Source: developed for this study (2019)

\section{Result and Discussion}

1. General principles of good governance in law number 5 of 2014

It has been previously explained that the General Principles of Good Governance are open concepts and are born of historical processes, because of that, there are various formulations regarding these principles. By Koentjoro and SF Marbun (Ridwan, 2016, p. 244), the general principles of good governance are as follows:

Table 1. General principles of good governance
1. principle of legal security
8. principle of principle of reasonable or prohibition of arbitrzriness
2.principle of principle of proportionality
9. principle of meeting raised expectation
3. principle of equality
10. principle of undoing the concequences of an annuled decision
4. principle of carefulness
11. principle of protecting the personal may of life
5. principle of motivation
12. principle of sapientia
6. principle of non misuse of competence
13. principle of public service
7. principle of fair play

In the following table it can be seen the types and number of general principles of good government contained in Law Number 5 Year 2014 concerning State Civil Apparatus:

Table 2. General Principles of Good Governance in Law No. 5 Year 2014

\begin{tabular}{ccc}
\hline NO & General Principles of Good Governance & Law Number 5 Year 2014 \\
\hline 1 & Principle of legal certainty & $\sqrt{ }$ \\
2 & Accountability Principle & $\sqrt{ }$ \\
3 & Principle of Proportionality & $\sqrt{ }$ \\
4 & Principle of Professionalism & $\sqrt{ }$ \\
6 & Principle of Efficiency & $\sqrt{ }$ \\
7 & Principle of Effectiveness & $\sqrt{ }$ \\
\hline
\end{tabular}




\begin{tabular}{ccc}
\hline 8 & Integrity Principle & $\sqrt{ }$ \\
9 & Delegation Principle & $\sqrt{ }$ \\
10 & Principle of Neutrality & $\sqrt{ }$ \\
11 & Principle of Unity & $\sqrt{ }$ \\
12 & Welfare Principle & $\sqrt{ }$ \\
& TOTAL & 12 \\
\hline
\end{tabular}

In the history of the emergence of good governance or general principles of good governance (Algemene Beginselen Van Behoorlijk Bestuur), this originated from a sense of fear of some people towards freedom of action (Freies Ermessen) from the state administration in implementing civil society arrangements to create a welfare state (Welfare State), among the writers of state administrative law there are differences in translation Algemene begins the behoorlijk van. The word begins there are interpreting with basic principles and principles while the word behorlijk is translated as the best that is proper and proper with this translation algemene beginselen van behoorlijk bestuur becomes principles or basics or general principles of good governance with reference to the original word berhoolijk, all of which indicate adjectives and means that there is an agreement, namely bestuur, then translation of the algorithm beginslen van berhoolijk bestuur becomes general principles $\mathrm{m}$ good governance would be more appropriate in terms of language.

What is meant by the general principles of good governance (algemene beginselen van behorlijk bestuur) is covering the meaning of general principles of good governance (algemene beginselen van behorlijk bestuur) covering legal certainty, orderly administration of the state, openness, professionalism, proportionality, and legal certainty, orderly administration of state, openness, professionalism, proportionality, and accountability, in law number 5 of 2014 concerning State Civil Apparatus there are several articles governing professional State Civil Servants, proportionality, clean from corrupt practices, collusion, and nepotism can hold public services in Indonesia provisions of article 2 of Law Number 5 Year 2014 onState Civil Apparatus formulate the principle of administering the State Civil Service as follows:

Article 2

The implementation of the policies and management of the country's civil apparatus is based on the principle:

Table 3. Provisions of article 2 of Act Number 5 Year 2014

\begin{tabular}{cc}
\hline a. Legal certainty & h. Effective and efficient \\
\hline b. Professionalism & i. Openness \\
c. Proportionality & j. Non-discrimination \\
d. Cohesiveness & k. Unity \\
e. Delegation & 1. Justice \\
f. Neutrality & m. Welfare. \\
g. Accountability & \\
\hline
\end{tabular}

In the explanation of Law Number 5 Year 2014 article 2 letter civil apparatus:

Table 4. Explanation of the General Principles of Good Governance

\begin{tabular}{ll}
\hline What is meant by & Explanation \\
\hline a. Principle of legal certainty & $\begin{array}{l}\text { It is in every implementation of policy and management of civil apparatus prioritizing } \\
\text { the basis of regulations, decency and fairness. }\end{array}$ \\
$\begin{array}{ll}\text { b. Principle of Professionalism } \\
\text { It is prioritizing expertise based on a code of ethics and statutory provisions. }\end{array}$ \\
$\begin{array}{ll}\text { It is prioritizing a balance between the rights and obligations of employees of the state } \\
\text { civil apparatus. }\end{array}$ \\
$\begin{array}{l}\text { It is the management of employees of the state civil apparatus based on a nationally } \\
\text { integrated management system. }\end{array}$ \\
$\begin{array}{l}\text { It is that part of the authority to manage the state civil apparatus can be delegated to the } \\
\text { implementation of the ministries, ministries of government and state governments. }\end{array}$ \\
$\begin{array}{l}\text { It is that every employee of the state civil apparatus does not take sides from any form of } \\
\text { influence and does not take sides with anyone's interests. }\end{array}$
\end{tabular}


g. Principle of accountability efficient

i. Principle of openness

j. Non-discriminatory principle

k. The principle of justice and equality

1. The principle of unity and unity

m. Welfare principle
It is that every activity and final outcome of the activities of employees of the state civil apparatus must be accountable to the community in accordance with the laws and regulations.

Is that in organizing the management of state civil apparatus in accordance with the target or goal in a timely manner in accordance with the stipulated plan.

It is that in the management of state civil apparatus management it is open to the public.

It is that in the management of the state civil apparatus, the State Civil Apparatus Commission does not distinguish between treatment of gender, ethnicity, religion, race and class.

It is that the arrangement of the implementation of the state civil apparatus must reflect a sense of justice and equality to get the opportunity for the functions and roles of the state civil apparatus.

It is the employee of the State civil apparatus is the glue of the unity of the unitary State of the Republic of Indonesia.

It is the implementation of the state civil apparatus aimed at realizing an increase in the quality of life of employees of the state civil apparatus.

In Articles 11 and 12 of Law Number 5 Year 2014 on State Civil Apparatus regulating the duties and roles of state civil apparatus in public service professionally and free from collusion, corrupt and nepotism practices.

\section{Article 11}

State Civil Service Officer on duty:

a. Carry out public policies made by staffing officials in accordance with the provisions of the legislation.

b. Providing professional and quality public services; and

c. Strengthening the unity and unity of the unitary state of the Republic of Indonesia.

Article 12

The state civil apparatus employee acts as an executor planner and supervisor of the implementation of general tasks of government and national development through the implementation of professional public policies and services that are free from collusion, corruption and nepotism.

Thus it is necessary to build a civil apparatus of professional countries free from clean political intervention from the practices of corruption, collusion and nepotism and able to provide public services for the community and be able to play a role as an adhesive element of national unity based on Pancasila and the 1945 Constitution.

2. The position of employees of the state civil apparatus.

Before speaking further about the state civil apparatus, first need to know what is meant by the state civil apparatus. The definition of the state civil apparatus itself is stated in article 1 number 1 of Law Number 5 Year 2014 which states that the state civil apparatus is a profession for Civil Servants and government employees with work agreements (PPPK) working for government agencies.

Civil Servants according to the Indonesian General Dictionary, are people who work for the government or state. According to Kranenburg Pegwai, the civilian state is the appointed official, so that understanding does not include those who hold positions representing members of parliament, the president and so on (Note 8).

The definition of civil servant government according to Mahfud MD there are two parts, namely:

a. Understanding of the Stipulative is the understanding given by the law concerning civil service officials as stated in article 1 number 3 of Law Number 5 Year 2014 which states that civil servants are Indonesian citizens who meet certain requirements, are appointed as permanent employees of the state civil apparatus by staffing officials to hold government positions.

b. Extensive understanding is an understanding that only applies to certain things. Certain things in question are more for some groups that are actually not civil servants. Example: the provisions of article 92 of the Criminal Code Theory and Platform for Forming the Law. Relating to the status of people's council members, members of the regional council and village head. According to article 92 of the Indonesian Criminal Code, it is explained that those who are included in the civil service are those who are elected in the general rules and those who are not elected but are appointed members of the people's council and members of the regional council and village heads and so on. The definition of civil service according to 
the Criminal Code is very broad, but the definition only applies in the case of people who commit crimes or violations of positions and other crimes mentioned in the Criminal Code, so this definition is not included in employment law.

Based on some of these meanings, it can be concluded that the State civil apparatus are people who work in a government agency in accordance with certain conditions set by the laws and regulations. In accordance with Law Number 5 Year 2014. Types, Status, and Position of State Civil Apparatus: Regarding the type of employee of the state civil apparatus regulated in article 6 of Law Number 5 Year 2014. Where employees of the state civil apparatus consist of civil servants and government employees with work agreements, speaking of the status of employees of the state civil apparatus, there are two statuses that apply to employees of the state civil apparatus, namely government employees appointed as permanent employees namely civil servants and government employees with work agreements. Regarding the status of state civil apparatus regulated in article 7 paragraph (1) and paragraph (2) Law Number 5 Year 2014 stating that:

(1). The State Civil Apparatus as referred to in Article 6 letter (b) is an employee of a state civil apparatus who is appointed as a permanent employee by a staffing official and has a national employee number.

(2). Government employees with work agreements as referred to in Article 6 letter b are employees of the state civil apparatus who are appointed as employees with employment agreements by staffing officials in accordance with the needs of Government Agencies and the provisions of this Act.

The formulation of the position of employees of the state civil apparatus is based on the points of mind that the government does not only carry out general functions of government, but also must be able to carry out the development function or in other words the government not only organizes government order, but also must mobilize and facilitate development for the benefit of the people many. C.F Strong, in his book entitled Modern Political Constitutions, argues that: "Government in the broader sense is charged with the maintenance of the peace and security of in a state therefore must have first, military power; second, the means of making laws; thirdly, financial, power or the ability to extract sufficient money from the comunity to defray the cost of defending the state and of enforcing the law it makes on the state behalf" (Note 9).

Employees of the state civil apparatus have a very important role because the employees of the state civil apparatus are elements of the state apparatus to organize and implement national government and development in order to achieve the country's goals. The smooth operation and implementation of government and national development in the context of achieving state goals is very dependent on the perfection of the state apparatus.

Speaking about the context of public law, employees of the state civil apparatus are tasked with assisting the president as head of government in organizing government, namely by implementing legislation, in the sense that the word is obliged to ensure that every law is adhered to by the people.

In implementing legislation in general, employees of the state civil apparatus are given official duties to be carried out as well as possible. As a servant of the state, an employee of the state civil apparatus must also be loyal and obedient to Pancasila as a philosophy and ideology of the state, to the 1945 Constitution of the Republic of Indonesia, to the state, and to the government. Employees of the state civil apparatus as elements of the state apparatus, state servants and public servants are required to be able to carry out the tasks of the national civil apparatus properly, therefore he must have loyalty, full obedience to Pancasila, 1945 Constitution of the Republic of Indonesia, the state and the government so that thoughts and directing all efforts and energy to carry out the tasks of government and development in an efficient and effective manner.

The position of the state civil apparatus under the 2014 Number 5 Year Law is regulated in article 8 where the state civil apparatus is located as an element of the state apparatus. Civil Servants as elements of the State Apparatus in carrying out the duties of the state civil apparatus, are obliged to maintain neutrality from the influence of political parties, are also obliged to maintain national unity and to carry out the duties of the civilian apparatus professionally and responsibly in carrying out government and development tasks and are clean and free from collusion and nepotism. The development of state apparatus is directed at increasing coordination between sectors, including the central and regional governments, as well as between regions and between regions to improve the quality and capability of state apparatus, functions of state institutions and government institutions, and their management to ensure smooth and integration of tasks and functions of the implementation of state government and development so that a cleaner and more authoritative state apparatus is realized, professionals of noble character, responsible, and exemplary.

In Law Number 5 Year 2014 on the State Civil Apparatus regulating the state personnel management which is compiled based on the framework of thinking that employees as individuals and as corps are an integral part of 
the government of the State. Therefore every civil servant is required to have full loyalty to the State government.

In essence the 1945 Constitution of the Unitary State of the Republic of Indonesia Article 4 paragraph (1) stipulates that the President of the Republic of Indonesia holds the power of government according to the Constitution. That is, the President is the highest organizer of the State. In carrying out the State administration, power and responsibility are entirely with the President. The State Administration ordered by the 1945 Constitution of the Republic of Indonesia is a democratic, decentralized, clean government from the practice of Collusion Corruption and Nepotism, and which is able to provide public services fairly. Provisions on the form of government as stated in various laws as the implementation of the 1945 Constitution of the Republic of Indonesia which is a sublimation of the noble ideals of the nation as stated in the 1945 Constitution of the Republic of Indonesia concerning good governance or good governance. To organize such a government it is necessary to develop a professional state apparatus, free from political intervention, clean from the practice of Collusion Corruption and Nepotism, high integrity, and capable and high performance.

The recently released World Bank publication, investing in Indonesia, Institutions for Inclusive and Sustainable Development shows the consequences of Indonesia's transformation into a middle-income country. Public demand for quality public services, and quickly will increase. To respond to the rising demand, the public sector must be able to provide the public services needed by middle income communities, such as better infrastructure, better public transportation, extension of compulsory education, international quality higher education, international standard health services, and adequate social security systems, including a health insurance system to finance more modern medical services. Faster reform of state apparatus is needed to build public service capacity, Indonesia provides higher public services that require high economic growth rates. As a middle-income nation and have a higher level of education, and have an increasingly democratic political life, the people have a higher political awareness. In such conditions, the Indonesian people will demand better, more affordable and high-quality public services, including high-quality education and health services, better transportation facilities and infrastructure, and state of the art communication advice. To meet the demands of public services that are on par with other developed countries, a professional state apparatus is needed, able to establish partnerships with private, high-performing, accountable, clean from the practice of Collusion Corruption and Nepotism, so that the level of welfare needs to be guaranteed.

Based on the 2014 Number 5 Year Law, the rights of the state civil apparatus are regulated in article 21. Where a civil servant is entitled to obtain certain things such as salary, allowances and facilities, leave, guarantee of pension and pension benefits, protection and competence development. Furthermore, the obligations of the employees of the state civil apparatus are all things that must be carried out according to the laws and regulation

\section{Conclusion}

Based on the results of previous research and discussion about state civil apparatus in Indonesia in the conception of welfare state (a study of legal material law number 5 year 2014 on state civil apparatus),associated with the function and position of the employees of the state civil apparatus conclude as follows:

- The Indonesian state is a welfare state which is an evolution from an ancient country that was only a night watchman. The consequence of the welfare state is that the state intervenes in all forms of community activities to ensure the implementation of public welfare. In this case the role of the government is very broad in interfering in community activities. The shift in the concept of Patronage State (nachwachtersstaat) to the concept of welfare state, shifts the role and activities of the government, to the welfare state concept, the government is given the obligation to realize General Welfare (bestuurszorg).

- The formulation of the position of employees of the state civil apparatus is based on the points of thought that the government not only carries out the general functions of government, but also must be able to carry out the development function or in other words the government not only organizes government order, but also must mobilize and facilitate development for the sake of many people.

- In Law Number 5 Year 2014 on state civil apparatus regulating the state personnel management which is arranged based on the framework that employees as individuals and as corps are an integral part of the government of the State. Therefore every civil servant is required to have full loyalty to the State government.

\section{References}

Anggara, S. (2012) Perbandingan Administrasi Negara. Pustaka Setia, Bandung.

Dicey, A. V. (1959). An Introduction to Study of Law of the Constitution. London: Mac, Millan \& Co. 
Hadjon, P. M. (2008). Hukum Tata Negara dan Hukum Administrasi untuk Mewujudkan Good Governance. FH, Unair, Surabaya.

Hartini, S. (2008). Hukum Kepegawaian di Indonesia. Sinar Grafika, Jakarta, hlm. 31.

Huda, N. (2005). Negara Hukum Demokrasi dan Judicial Review. Yogyakarta: UII Press.

Kumorotomo. (1999). Etika Administrasi Negara. Rajawali Press,Jakarta.

Moh. Mahfud, M. D., \& Marbun, dan S. F. (1987). Pokok-pokok Hukum Administrasi Negara, Liberty, Yogyakarta.

Muhammad, M. (2017). Etika Administrasi Negara. Deepublish, Yogyakarta.

Muhammad, M. (2018). Independensi, Yudisial, Sebagai, Pilar, Dari, Suatu, Negara, Hukum. Retrieved from https://merajajournal.merajamedia.com/index.php/mrj/article/view/7

Muhammad, M. (2019). General Principles of Good Governance (ALGEMENE BEGINSELEN VAN BEHOORLIJK BESTUUR) In State Civil Apparatus Law (A study of the general principles of good governance in law number 5 of 2014 on State Civil Apparatus.) IJISRT, 4(1). Retrieved from https:/ijisrt.com/general-principles-of-good-governance-algemene-beginselen-van-behoorlijk-bestuur-in-sta te-civil-apparatus-law-a-study-of-the-general-principles-of-good-governance-in-law-number-5-of-2014-onstate, Scribd: https://goo.gl/suX1xQ

Pramukti, A. S. (2016). Pengawasan Hukum Terhadap Aparatur sipil negara. Pustaka Yustisia, Yogyakarta.

Ridwan, H. R. (2016). Hukum Administrasi Negara (Edisi Revisi). Rajagrafindo Persada, Jakarta, hlm $229,244$.

Sabine, G. (1995). A History of Political Theory. London: G. Harrap Co.Ltd.

Sampara, S., \& Husen, L. O. (2016). Metode Penelitian Hukum (edisi revisi). Kretakupa Print, Makassar.

Soekanto, S. (2014). Penelitian Hukum Normatif suatu Tinjauan Singkat. Raja Grafindo Persada, Jakarta.

Strong, C. F. (1960). Modern Political Constitution. London: Sidgwick \& Jonson Ltd.

Ten Berge, J. B. J. M. (1995). Bescherming Tegen Overheid. W.E.J.Tjeenk Willink, Zwolle.

Thoha, M. (1991). Beberapa Aspek Kebijakan Birokrasi. Mandala, Yogyakarta.

Utrecht, E. (1957). Pengantar dalam Hukum Indonesia. Ichtiar, Jakarta, hlm 30.

\section{Notes}

Note 1. Kumorotomo, 1999, Etika Administrasi Negara, Rajawali Press.

Note 2. Miftah Thoha, 1991, Beberapa Aspek Kebijakan Birokrasi, Mandala, Yogyakarta.

Note 3. Sahya Anggara, 2012, Perbandingan Administrasi Negara, Pustaka Setia. Hlm 52-53.

Note 4. Anggar Sigit Pramukti, 2016, Pengawasan Hukum terhadap Aparatur Negara, Pustaka Yustisia, Yogyakarta.

Note 5. Utrecht, E, 1957, Pengantar dalam Hukum Indonesia, Ichtiar, Jakarta.hlm 30.

Note 6. Ridwan HR, 2016, Hukum Administrasi Negara (Edisi Revisi), Raja Grafindo, jakarta hlm 229.

Note 7. H.J.Van Eikema Hommes, dalam Sarjono Soekanto, op, cit., hlm.65.

Note 8. Sri Hartini, 2008, Hukum Kepegawaian di Indonesia, Sinar Grafika, Jakarta., hlm.31.

Note 9. CF.Strong, 1960, Modern Political Constitution, Sidgwijk \& Jakson Ltd, London., hlm.6.

\section{Copyrights}

Copyright for this article is retained by the author(s), with first publication rights granted to the journal.

This is an open-access article distributed under the terms and conditions of the Creative Commons Attribution license (http://creativecommons.org/licenses/by/4.0/). 